\title{
Utilization of subtropical seagrass meadows by newly settled red drum Sciaenops ocellatus: patterns of distribution and growth
}

\author{
Jay R. Rooker*, Scott A. Holt \\ The University of Texas at Austin, Marine Science Institute, 750 Channelview Drive, Port Aransas, Texas 78373, USA
}

\begin{abstract}
A.BSTRACT: Spatial and temporal variability in distribution and growth of newly settled red drum Sciaenops ocellatus were examined in the Aransas Estuary, Texas, USA. Overall, 1891 red drum larvae and early juveniles ( 4 to $30 \mathrm{~mm}$ standard length, SL) were identified from weekly epibenthic sled collections taken during the annual recruitment period (September-December 1994). Densities ranged from 0.0 to 3.4 ind. $\mathrm{m}^{-2}$, with peak values observed in mid to late October. Density varied significantly between habitats (Halodule wrightii vs Thalassia testudinum) and among sites. Otolith-based techniques were used to determine hatch-date distributions and individual growth rates of newly settled red drum. Hatch dates of individually aged red drum $(n=324)$ ranged from September 4 to October 30 (57 d). Hatch dates were used to separate individuals into 10 -d cohorts and cohort-specific growth rates were estimated from exponential size-at-age plots. Cohort-specific instantaneous growth coefficients (g) ranged from 0.041 to $0.058 \mathrm{~d}^{-1}$ with highest values occurring for mid-season cohorts. Spatial and temporal patterns of recent growth (mean increment width over 5 d) were also investigated. Recent growth rates were highest for mid-season cohorts and relatively uniform between habitats and among sites. Since spatial trends in density were not explained by growth differences, we hypothesize that factors other than growth potential were influencing the distribution of newly settled red drum in the Aransas Estuary
\end{abstract}

KEY WORDS: Distribution . Growth - Hatch date - Otolith increments - Recruitment - Red drum . Seagrass

\section{INTRODUCTION}

Variability in growth rates of marine fish larvae and early juveniles can play a significant role in the regulation of recruitment and year-class strength (Houde 1987, Leggett \& Deblois 1994). Rapid growth during early life stages is essential since predation-mediated mortality is typically high (Houde 1987, Sinclair 1988) and size-dependent (Miller et al. 1988, Fuiman 1989, Gamble \& Hay 1989). Individuals that grow rapidly will achieve a larger body size at a given age and thus spend less time (i.e. reduced stage duration) in the vulnerable size ranges (Bailey \& Houde 1989, Post \&

\footnotetext{
·E-mail: rooker@utmsi.zo.utexas.edu
}

Evans 1989). Moreover, swimming speed and ability to detect and escape predators will be enhanced for larger individuals (Webb \& Corolla 1981, Bailey \& Houde 1989, Fuiman 1994, Fuiman \& Magurran 1994).

Otolith microstructure techniques are commonly used to evaluate growth rates of marine fish larvae and juveniles (e.g. Geffen 1982, Jones 1986, Radtke 1989, Sogard \& Able 1992, Moksness et al. 1994, Secor \& Houde 1995). As Pannella (1971) demonstrated, ages of individuals can be estimated by enumerating daily growth increments. Once size-at-age is determined, growth rates can be quantified. Recent advances in fish otolith research have elucidated additional applications of otolith microstructure techniques for growth studies. A linear coupling of otolith growth to somatic growth has been reported for many species (e.g. Broth- 
ers 1981, Wilson \& Larkin 1982, Volk et al, 1984, Sogard 1991). As a result, increment widths are potentially useful for evaluating daily growth rates. Measuring a series of increment widths near the periphery of the otolith has proven useful as a means of estimating recent growth rates during early life stages (Suthers et al. 1989, Hovenkamp \& Witte 1991, Sogard \& Able 1992).

The red drum Sciaenops ocellatus is a primary component of the recreational fishery throughout the coastal waters of the Gulf of Mexico (Swingle 1990, NOAA 1991). Spawning occurs in early fall (September-November; Comyns et al. 1991) in offshore waters and areas near tidal inlets that connect the Gulf of Mexico to inshore estuarine habitats (Holt et al. 1983, Peters \& McMichael 1987). Tidal currents move larvae through passes, and red drum settle into demersal seagrass habitats at approximately 6 to $8 \mathrm{~mm}$ standard length (Holt et al. 1983, Peters \& McMichael 1987). Although utilization of estuarine seagrass meadows by newly settled red drum is fairly well documented, our understanding of growth variation during this interval is extremely limited.

In this study, otolith-based methods were used to determine individual growth rates of newly settled red drum from seagrass habitats in south Texas. The primary aim of our research was to obtain baseline estimates of growth and identify the biotic and abiotic sources affecting growth. Specifically, cohort-, habitat-, and site-specific growth rates were estimated. In addition, spatial and temporal variability in density of newly settled red drum were examined in conjunction with growth to assess the quality of different nursery areas.

\section{METHODS}

Field collections. Newly settled red drum were collected from 4 sites in the Aransas Estuary, Texas [Aransas Bay 1 and 2 (AB1, AB2), Redfish Bay (RB), and Corpus Christi Bay (CB)] during the annual recruitment period [September to December 1994 (Fig. 1)]. At 1 site within each bay (AB1, RB, CB), cooccurring monotypic stands of the 2 primary seagrass species found in south Texas, shoal grass Halodule wrightii and turtle grass Thalassia testudinum, were present and sampled separately to evaluate the habitat effect. Site AB2 consisted of only a $H$. wrightii station. Collections were taken weekly from $H$. wrightii stations, while $T$. testudinum stations were sampled biweekly. At each paired site, monotypic stands (>90\% single species) were within $50 \mathrm{~m}$ of each other. All collections were made using an epibenthic sled, with an opening measuring 0.75 (l) $\times 0.5$ (h) $\mathrm{m}$,

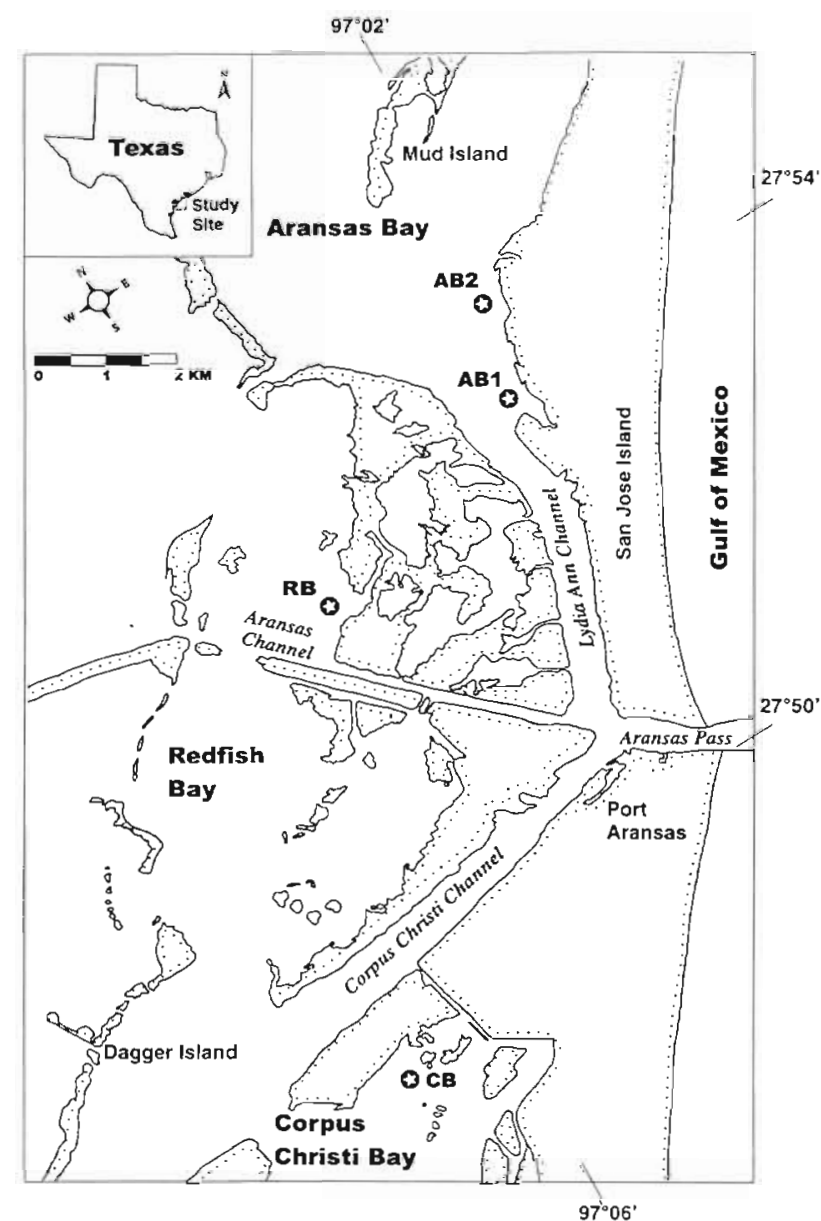

Fig. 1. Location of the 4 sampling sites in the Aransas Estuary, Texas, USA: Aransas Bay (AB1, AB2), Redfish Bay (RB), and Corpus Christi Bay (CB)

equipped with a $505 \mu \mathrm{m}$ conical plankton net. Collections were taken by hand towing the sled at a constant speed $\left(0.7 \mathrm{~m} \mathrm{~s}^{-1}\right)$ through selected stands of seagrass. Triplicate $20-\mathrm{m}$ sled tows were made at each sampling station on each trip. The capture efficiency of the sled was evaluated in preliminary trials (comparison of different gear types) and size-specific differences in gear avoidance were not evident for individuals $\leq 20 \mathrm{~mm}$ (Rooker 1997). Individuals were preserved in $95 \%$ ethanol immediately after capture. Standard lengths (SL) of individual red drum were measured to the nearest $0.1 \mathrm{~mm}$ prior to otolith extraction and no adjustments for shrinkage were made. Environmental data collected at each site included depth, salinity, water temperature, and time of day.

Otolith procedures. Lapillar otoliths were removed from selected individuals and cleaned of tissue. Whole otoliths were then mounted on petrographic slides using the polymer mounting medium Flo-texx and 
allowed to harden (24 h). Increment counts, increment widths, and radius of each lapillus were measured under light microscopy using an image analysis system (Optimas, Bioscan). Otolith measurements were made using a microscope magnification of 200 to $500 \times$. Light microscopy was deemed appropriate (vs scanning electron microscopy) for red drum lapilli because average increment widths (5 to $7 \mu \mathrm{m}$ ) were well above light microscope resolution limits $(<1 \mu \mathrm{m}$; Campana \& Neilson 1985). Radius, increment count, and increment width measurements were made along a straight line from the primordium to the posterior edge. Since otolith growth is allometric (Campana \& Neilson 1985), all measurements were taken in the same field. The daily deposition of increments was validated in our laboratory by chemically marking (Alizarin complexone) the lapillar otoliths of knownage red drum.

Otolith-derived age was determined by enumerating all growth increments from the primordium to the periphery of the otolith. Inner increments (proximal to the primordium) on the lapilli of red drum are unclear and difficult to enumerate. Attempts to improve the readability near the primordium by polishing did not provide better resolution of the inner increments. To accurately determine the age of wild red drum, it was necessary to develop a relationship between age and otolith radius which could be used to predict the number of growth increments at various distances from the primordium (i.e. within the unclear region). The relationship was described as

$$
\text { Age }=34.46+15.94 \log (\text { Radius })\left(r^{2}=0.96, n=50\right)
$$

where age and radius are in days and $\mathrm{mm}$, respectively. The actual age was determined by adding the predicted age from the unreadable section (correction factor from age-radius relationship) to the increment count number of increments from first identifiable increment to edge of lapillus). Correction factors generally accounted for less than $25 \%$ of the actual age estimate and the relative size of the correction did not differ among cohorts. The relationship was determined from known-age fish in laboratory trials. To insure that the model accurately reflected growth rates of natural populations, we only selected laboratory-reared individuals displaying growth rates comparable to previously described estimates of wild red drum larvae (Comyns et al. 1989). Instantaneous growth rates reported by Holt (1993) in controlled conditions were also very similar to these values.

Hatch dates of individual red drum were determined by subtracting the otolith-derived age (i.e. increment count) from the date of collection. Hatch dates were then used to separate individuals into specific cohorts, defined as individuals hatched within a 10-d period.
Each cohort was designated by a letter (A to F): Sep 110 (A), Sep 11-20 (B), Sep 21-30 (C), Oct 1-10 (D), Oct 11-20 (E). Oct 21-30 (F). Cohort-specific growth rates were estimated from an exponential model described as:

$$
L_{t}=a e^{g !}
$$

where $L_{t}=\mathrm{SL}(\mathrm{mm}), a$ = estimated length at hatch (age 0 ), $g=$ instantaneous growth coefficient $\left(\mathrm{d}^{-1}\right)$, and $t=$ otolith-derived age (d post-hatch). Estimates of cohort-specific growth were based on samples from one site (AB2). Age and hatch dates for red drum not assessed with otolith-based methods ( $\mathrm{n}=1543$ ) were derived using an age-length key. An age-specific mortality function $\left[\log _{\mathrm{e}} N_{1}=10.786-0.139(\right.$ Age $), \mathrm{r}^{2}=0.91$, based on individuals age 20 to $40 \mathrm{~d}$ ( 8 to $20 \mathrm{~mm}$ ); Rooker 1997] was applied to the hatch-date distribution to adjust for differences in mortality among different-sized red drum. This adjustment was necessary because older red drum have spent more time in the early life phase than younger individuals and, as a result, experienced greater mortality. Age-specific mortality adjustments were made to each cohort (hatch date) using the equation described by Brown \& Bailey (1992):

$$
N_{i, j}=\frac{N_{i}}{\mathrm{e}^{-Z(i-j)}}
$$

where $N_{i, j}$ is the abundance of age $i$ individuals of a cohort adjusted for mortality $(Z)$ to the age of the youngest individual (j) represented (= $20 \mathrm{~d}$ ). Due to incomplete capture (i.e. ascending limb of catch curve) of the earliest red drum recruits (ca 15 to $19 \mathrm{~d}$ ), mortality estimates could not be calculated for these individuals. Consequently, the mortality adjustment for these individuals was determined by applying the mortality rate of $20 \mathrm{~d}$ individuals.

Since red drum spend a significant portion of their early life in the pelagic environment (ca 15 to 20 d), analysis of growth variation in different demersal seagrass habitats and sites required an alternative approach. Estimates of recent growth were necessary to properly evaluate spatial variability in growth rates during the early post-settlement period. We evaluated recent growth by measuring the widths of the 5 increments nearest the periphery of the otolith. The mean width of the 5 recent growth increments prior to capture was used as an index of recent growth. Variation in increment widths was assumed to result from differences in somatic growth during the $5 \mathrm{~d}$ period prior to the day of capture. The use of increment widths as a measure of recent growth relies on the assumption that otolith growth corresponds to somatic growth. In this study, the otolith radius was linearly related to the SL of wild-caught red drum (Fig. 2). 


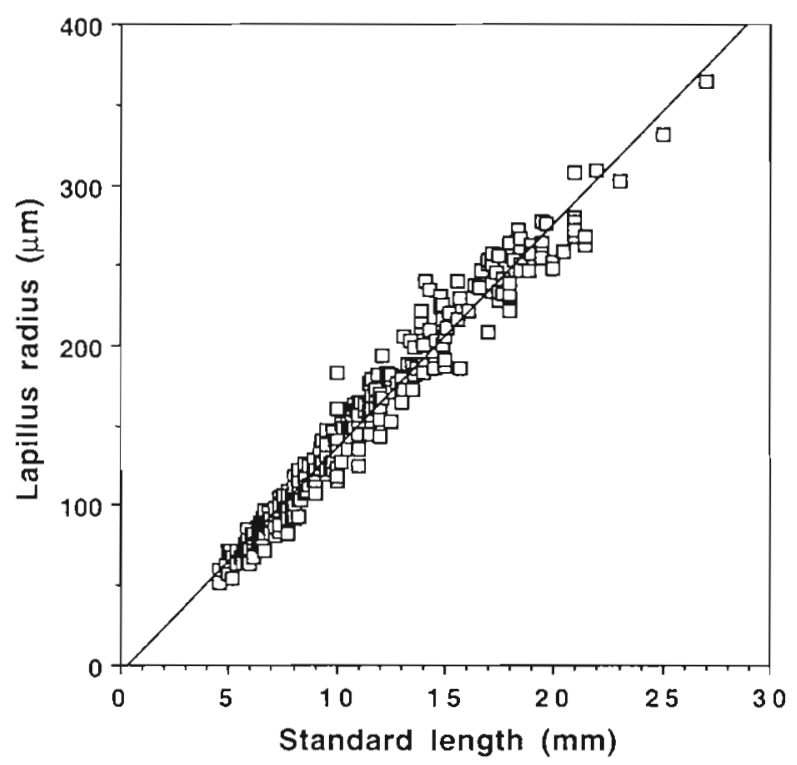

Fig. 2. Sciaenops ocellatus. Linear relationship between lapillus radius and standard length for red drum larvae and juveniles collected from the Aransas Estuary. Regression model: Radius $=-5.097+13.971 \mathrm{SL} ; \mathrm{n}=348, \mathrm{r}^{2}=0.96$

The left and right lapilli of 258 red drum were analyzed and estimates of age and recent growth were derived by averaging readings from both otoliths. The average differences in age and mean increment width $(5 \mathrm{~d}$ ) were $3.6 \%$ (range 0 to $14 \%$ ) and $8.8 \%$ (range 0 to $31 \%$ ), respectively. For the remaining individuals ( $n=66$ ) only 1 of the lapillar otoliths was used. For 24 individuals, growth increment analysis was not possible due to heavy staining on lapillar otoliths. Overall, lapillar otoliths from 348 individuals were examined.

Data analysis. Analysis of covariance (ANCOVA) was used to test for spatial and termporal differences in growth. The assumption of no interaction between the treatment and covariate was first examined to determine if slopes differed (Sokal \& Rohlf 1981). The main significance test of the ANCOVA (homogeneity of $y$-intercepts) was performed only when the assumption of parallelısm of slopes was met. A multiple regression model was developed to identify abiotic and biotic factors which could affect otolith increment widths. Factors identified as significant parameters in the model were adjusted for when comparing recent growth over different spatial and temporal scales. Analysis of variance (ANOVA) was used to examine spatial and temporal variability in density. Estimates of density were log-transformed to minimize heteroscedasticity of the data. Tukey's honestly significant difference (HSD) test was used to determine which levels of the main effect differed significantly $(\alpha=0.05)$ from other levels.

\section{RESULTS}

\section{Environmental variability}

Mean daily estimates of water temperature and salinity from the Aransas Pass during August-December, 1994, indicated that temporal variation in both parameters was pronounced (Fig. 3). Temperature and salinity ranged from 19.1 to $30.7^{\circ} \mathrm{C}$ and 25.0 to $37.4 \%$. Peak values for both parameters occurred during the initial spawning period and declined for later spawning and settlement dates. Although these 2 parameters were not monitored daily in the Aransas Estuary, weekly measurements were recorded at the different sampling sites and habitats. Temporal patterns in temperature observed in the Aransas Estuary closely matched recordings at the Aransas Pass, but the magnitude of these fluctuations was more pronounced in the shallow water habitats of the estuary. On average, water depths in Thalassia testudinum habitats were 10 to $20 \mathrm{~cm}$ greater than Halodule wrightii 10.58 and $0.44 \mathrm{~m}$, respectively); however, temperature regimes did not appear to differ substantially between habitats. Differences in salinity between seagrass habitats and the Aransas Pass were minimal.

\section{Spatial and temporal distribution}

A total of 1891 red drum larvae and early juveniles ( 4 to $30 \mathrm{~mm} \mathrm{SL}$ ) was identified from 210 benthic sled collections taken from 13 September to 5 December, 1994, in the Aransas Estuary (Table 1). Densities ranged from 0.0 to 3.4 ind. $\mathrm{m}^{-2}$ over the entire sampling period, with peak values observed in mid to late October. A 2-way ANOVA was used to evaluate the effects of date and site on density of red drum collected from Halodule wrightii stations. Date and site were identified as significant factors $(p<0.001)$. The first order interaction (date $\times$ site) was also significant $(p<0.001)$, indicating that the magnitude of differences between $H$. wrightii sites was not consistent over time. Overall, densities were approximately 3 -fold higher in $\mathrm{AB} 1$ and $A B 2$ than $C B$ or $R B$. To evaluate the influence of habitat on density of red drum, a 3-way ANOVA (factors: date, habitat, site) was performed on a limited data set: samples collected bi-weekly from paired stations (AB1, $R B, C B)$. A significant difference $(p=0.040)$ in red drum density was observed between $H$. wrightii and Thalassia testudinum. Over $75 \%$ of all individuals collected in paired comparisons were taken from $H$. wrightii habitat. Similar to the previous analysis, date and site were identified as significant $(p<0.001)$ sources of variation in red drum density. Moreover, significant $(p<0.001)$ date $\times$ site and date $\times$ habitat 
Fig. 3. Daily water temperature and salinity records from the Aransas Pass in 1994. Hatch dates (10-d range) of red drum cohorts $A$ to $F$ are given

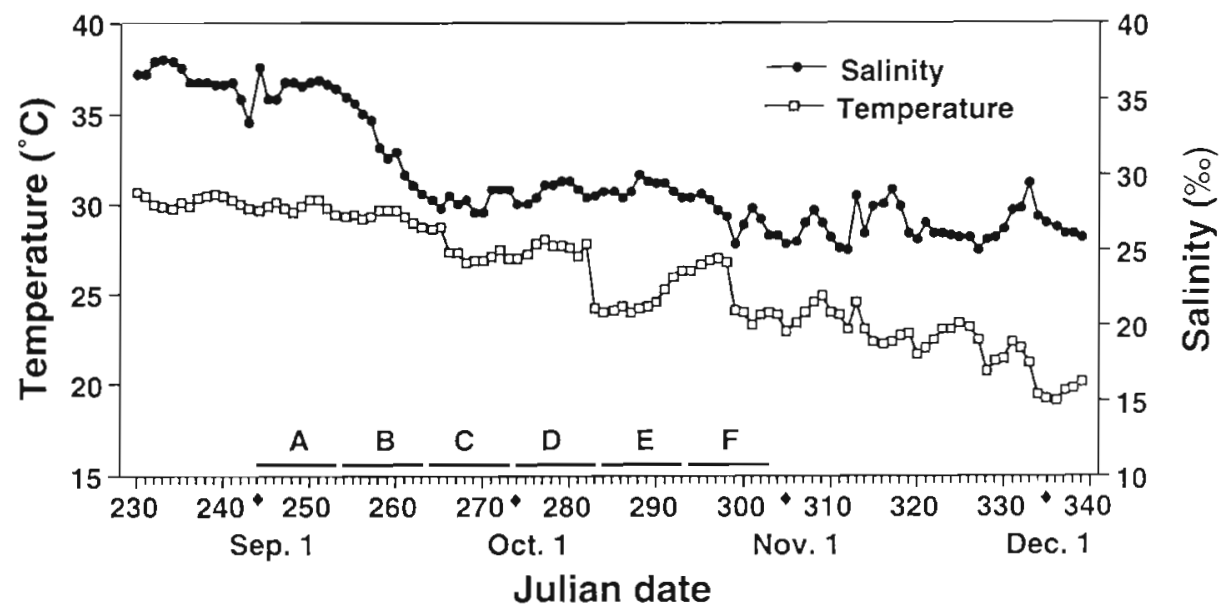

Table 1. Sciaenops ocellatus. Densities (ind. $\mathrm{m}^{-2}$ ) of newly settled red drum collected from seagrass habitats in the Aransas Estuary, Texas, USA (1994). Estimates are given by habitat, station, and sampling date for red drum larvae and early juveniles (4 to $30 \mathrm{~mm} \mathrm{SL}$ ). Each density estimate is based on 3 replicate benthic sled tows. Station locations are shown in Fig. 1

\begin{tabular}{|c|c|c|c|c|c|c|c|c|c|c|}
\hline \multirow[t]{2}{*}{ Date } & \multicolumn{5}{|c|}{ Halodule wrightii } & \multicolumn{4}{|c|}{ Thalassia testudinum } & \multirow{2}{*}{$\begin{array}{l}\text { Mean SL } \\
(\mathrm{mm})\end{array}$} \\
\hline & $\mathrm{RB}$ & $\mathrm{CB}$ & $A B 1$ & $\mathrm{AB} 2$ & Average & $\mathrm{RB}$ & CB & AB1 & Average & \\
\hline $13 \mathrm{Sep}$ & 0.00 & 0.00 & 0.04 & 0.00 & 0.01 & - & - & - & - & 7.0 \\
\hline 22 Sep & 0.00 & 0.00 & 0.00 & 0.09 & 0.02 & - & - & - & - & 8.0 \\
\hline $27 \mathrm{Sep}$ & 0.02 & 0.02 & 0.02 & 0.93 & 0.25 & 0.00 & 0.00 & 0.02 & 0.01 & 7.6 \\
\hline 4 Oct & 0.18 & 0.42 & 1.36 & 1.93 & 0.97 & - & - & - & - & 8.1 \\
\hline $11 \mathrm{Oct}$ & 3.33 & 0.33 & 1.64 & 0.89 & 1.55 & 0.62 & 0.00 & 0.51 & 0.38 & 7.1 \\
\hline 17 Oct & 0.47 & 0.84 & 0.80 & 1.82 & 0.98 & - & - & - & - & 8.2 \\
\hline 24 Oct & 0.38 & 0.53 & 1.22 & 2.13 & 1.07 & 0.09 & 0.11 & 0.29 & 0.16 & 9.2 \\
\hline 31 Oct & 0.16 & 0.20 & 2.73 & 3.36 & 1.61 & - & - & - & - & 10.3 \\
\hline 7 Nov & 0.02 & 0.16 & 2.51 & 1.96 & 1.16 & 0.27 & 0.00 & 1.38 & 0.55 & 12.4 \\
\hline 16 Nov & 0.11 & 0.00 & 2.71 & 1.69 & 1.13 & - & - & - & - & 14.9 \\
\hline 21 Nov & 0.00 & 0.07 & 0.31 & 0.40 & 0.19 & 0.00 & 0.00 & 0.04 & 0.01 & 18.1 \\
\hline 29 Nov & 0.00 & 0.13 & 0.20 & 0.13 & 0.12 & - & - & - & - & 18.6 \\
\hline $5 \mathrm{Dec}$ & 0.00 & 0.00 & 0.13 & 0.20 & 0.08 & 0.02 & 0.02 & 0.02 & 0.02 & 20.1 \\
\hline Average (all dates) & 0.36 & 0.21 & 1.05 & 1.19 & 0.70 & 0.17 & 0.02 & 0.38 & 0.19 & \\
\hline
\end{tabular}

interactions were present, suggesting that the relative magnitude of differences in density between habitats and among sites was not uniform over sampling dates.

\section{Hatch-date distribution}

The hatch-date distribution of red drum aged directly from otolith increment counts $(n=324)$ ranged from 4 September to 30 October (57 d). A size-at-age model was then used to estimate the hatch dates of remaining red drum from length-frequency data $(\mathrm{n}=$ 1543) and a hatch-date distribution for all red drum was estimated. Overall, hatch dates occurred over a $64 \mathrm{~d}$ period ranging from 29 August to 31 October (Fig. 4). The application of the age-specific mortality correction to these data resulted in a redistribution of hatch-date frequencies. Although the relative number of fish hatched was highest in late September through early October in both distributions, the mortality-corrected distribution shifted percent frequency estimates toward the later hatch dates. Thus, the relative frequencies of early spawned individuals (i.e. 10 to 16 September) was reduced and certain periods after 1 October were emphasized.

\section{Cohort-specific growth}

Cohort-specific instantaneous growth coefficients $(g)$ for red drum from Aransas Bay (AB2) ranged from 0.041 to $0.058 \mathrm{~d}^{-1}$ (Table 2), and a significant cohort effect was detected (ANCOVA, different slopes, $p=$ 0.016 ). Growth rates were highest for mid-season cohorts (C, D) and lowest for early and late cohorts [A, $B$ and $E, F$, respectively (Fig. 5)]. The instantaneous 


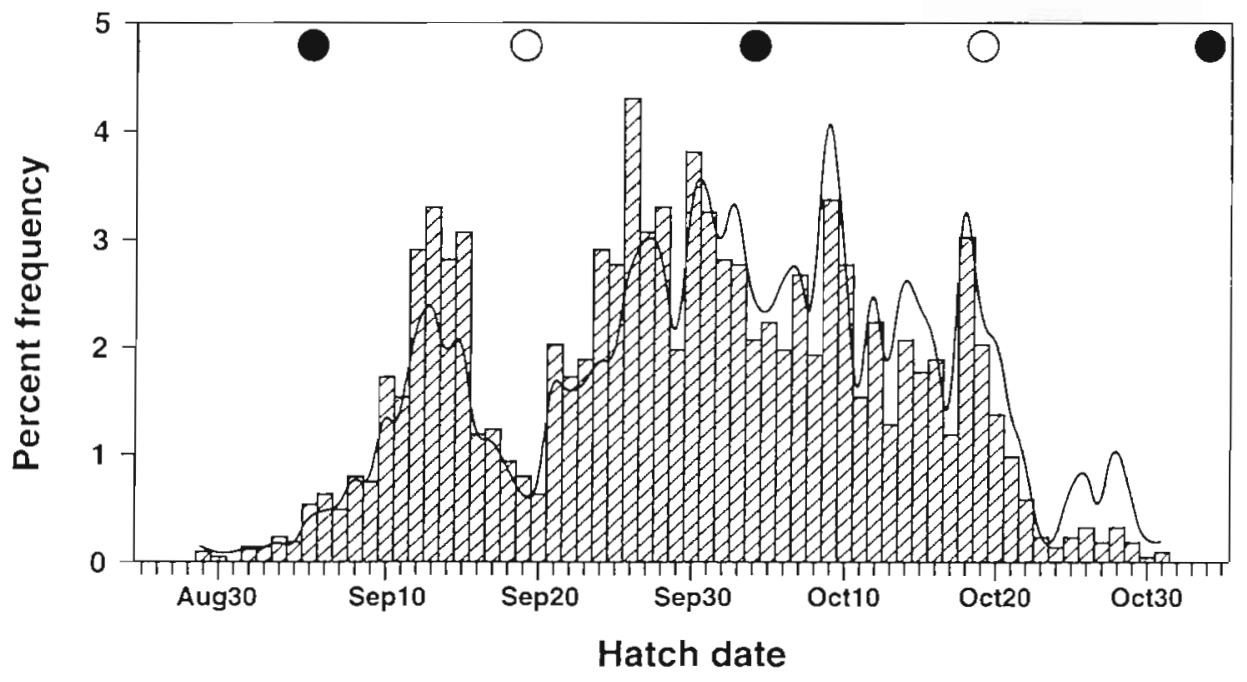

Fig. 4. Sclaenops ocellatus. Hatch-date distributions of red drum estimated from otolithbased estimates of age of larvae and juveniles collected from the Aransas Estuary in 1994 Distributions are shown with (continuous line) and without (bars) an age-specific correction to adjust for differential mortality rates (see text). New (O) and full (O) lunar phases are shown

Table 2. Sciaenops ocellatus. Instantaneous growth coefficients $(g)$, estimated growth rate ( $\mathrm{mm} \mathrm{d}^{-1}$ ), and size-at-age (mm SL) for successive cohorts of newly settled red drum in Aransas Bay (AB2), Texas, USA, 1994. Recent growth rates [mean otolith increment width $\left.\left(\mu \mathrm{m} \mathrm{d}^{-1} \pm \mathrm{SE}\right)\right]$ are also shown for each cohort

\begin{tabular}{|lccccccc}
\hline Cohort & $g\left(\mathrm{~d}^{-1}\right)$ & $\begin{array}{c}0-20 \mathrm{~d} \\
\left(\mathrm{~mm} \mathrm{~d}^{-1}\right)\end{array}$ & $\begin{array}{c}20-40 \mathrm{~d} \\
\left(\mathrm{~mm} \mathrm{~d}^{-1}\right)\end{array}$ & $\begin{array}{c}20 \mathrm{~d} \\
(\mathrm{~mm} \mathrm{SL})\end{array}$ & $\begin{array}{c}30 \mathrm{~d} \\
(\mathrm{~mm} \mathrm{SL})\end{array}$ & $\begin{array}{c}40 \mathrm{~d} \\
(\mathrm{~mm} \mathrm{SL})\end{array}$ & $\begin{array}{c}\text { Recent } \\
\text { growth }\end{array}$ \\
\hline A & 0.041 & 0.22 & 0.50 & 7.94 & 11.96 & 18.02 & $6.81 \pm 0.33$ \\
B & 0.046 & 0.23 & 0.57 & 7.60 & 12.03 & 19.07 & $7.16 \pm 0.15$ \\
C & 0.058 & 0.26 & 0.82 & 7.48 & 13.37 & 23.87 & $7.24 \pm 0.16$ \\
D & 0.051 & 0.26 & 0.71 & 7.98 & 13.29 & 22.12 & $7.49 \pm 0.13$ \\
E & 0.048 & 0.24 & 0.63 & 7.76 & 12.54 & 20.27 & $7.06 \pm 0.18$ \\
F & 0.044 & 0.23 & 0.55 & 7.84 & 12.17 & 18.89 & $7.19 \pm 0.35$ \\
A-F & 0.048 & 0.24 & 0.62 & 7.72 & 12.48 & 20.16 & $7.24 \pm 0.08$ \\
\hline
\end{tabular}

growth coefficient at $A B 2$ for the entire season (all cohorts pooled) was $0.048 \mathrm{~d}^{-1}$. Similarly, when samples from all sites were pooled, growth was estimated at $0.050 \mathrm{~d}^{-1}$.

Exponential models derived from size-at-age data were used to estimate cohort-specific growth rates $\left(\mathrm{mm} \mathrm{d}^{-1}\right)$ at 2 intervals: 0 to $20 \mathrm{~d}$ and 20 to $40 \mathrm{~d}$ (Table 2). Mean growth rates among cohorts ranged from 0.22 to $0.26 \mathrm{~mm} \mathrm{~d}^{-1}$ at the 0 to $20 \mathrm{~d}$ interval and 0.50 to $0.82 \mathrm{~mm} \mathrm{~d}^{-1}$ at the 20 to $40 \mathrm{~d}$ interval. Peak values were observed for individuals hatched during the middle of the spawning season (cohorts $C$ and D). In addition, length-at-age of different cohorts was estimated from these models at 20,30, and $40 \mathrm{~d}$ post-hatch (Table 2). Mean length among cohorts ranged from 7.5 to $8.0,12.0$ to 13.4 , and 18.0 to $23.9 \mathrm{~mm} \mathrm{SL}$ at Days 20,30, and 40, respectively.

To assess the influence of temperature, cohort-specific estimates of mean growth rate $\left(\mathrm{mm} \mathrm{d}^{-1}\right)$ and length-at-age ( $\mathrm{mm} \mathrm{SL}$ ) were compared to mean daily water temperature (20 d average) using regression analysis. During the 2 intervals examined 10 to $20 \mathrm{~d}$ and 20 to $40 \mathrm{~d}$ ) mean growth rates were not significantly related to temperature $(0$ to $20 \mathrm{~d}, \mathrm{p}=0.621 ; 20$ to $40 \mathrm{~d}, \mathrm{p}=0.874$ ). Similarly, predicted lengths at 20,30 , and $40 \mathrm{~d}$ were not significantly related to temperature $(p=0.810,0.738$, and 0.810 , respectively)

\section{Recent $5 \mathrm{~d}$ growth index}

The index of recent growth (mean increment width over 5 d) was initially analyzed with a multiple regression model to identify potential confounding factors which would limit the usefulness of spatial and temporal comparisons. Mean water temperature (daily mean based on $5 \mathrm{~d}$ prior to capture) and SL were identified as significant $(p<0.001)$ factors in the model. These 2 factors explained $33 \%$ of the variability in recent growth. To evaluate these factors in greater detail, an ANCOVA model was developed with SL (mm) as the covariate, water temperature $\left({ }^{\circ} \mathrm{C}\right)$ as a factor, and 
mean increment width ( $\mu$ m) as the dependent variable. Increment width was correlated positively with length and a linear model predicted that increment width increased by approximately $2 \%$ per mm increase in length (Increment width $=5.300+0.152 \mathrm{SL}, \mathrm{n}=324, \mathrm{r}^{2}=$ $0.26)$. Residuals from the SL-increment width relationship were then used to estimate adjusted increment widths (least squares means) at the different water temperatures. Adjusted mean increment width increased by approximately $2 \%$ per ${ }^{\circ} \mathrm{C}$ increase in temperature (Increment width $=3.246+$ 0.153 Temperature, $n=8, r^{2}=0.46$ )

Adjustments for the effects of SL on recent growth rates of red drum were required when evaluating spatial and temporal patterns. To do this we used an ANCOVA with SL as the covariate to adjust for the length effect. Moreover, to compensate for temperature differences, habitat and site comparisons were performed on samples collected over a limited interval (14 d) when daily mean water temperature was relatively constant. An ANCOVA was performed on individuals from this limited interval and temperature was not significantly $(p=0.450)$ related to mean increment width.

Recent growth rates were not significantly different between habitats (ANCOVA, $\mathrm{p}=0.664, \mathrm{n}=73$ ). Adjusted mean increment widths for red drum from Halodule wrightii and Thalassia testudinum habitats were $6.69 \mu \mathrm{m}$ $(\mathrm{SE}=0.11)$ and $6.37 \mu \mathrm{m}(\mathrm{SE}=0.19)$, respectively (Fig. 6). Since no habitat effect was observed, estimates from different habitats were pooled when examining recent growth variation by site. Significant differences (ANCOVA, $p=0.005, n=142$ ) were detected among the 4 sites examined. Mean increment widths ranged from 6.26 to $7.08 \mu \mathrm{m}$, with peak values observed at AB2 (Fig. 6). Tukey's HSD test $(\alpha=0.05)$ indicated that the mean increment width at $A B 2$ was significantly higher than the other 3 sites ( $A B 1, R B, C B$ ); however, mean increment widths at these 3 sites were not significantly different from one another. In addition to spatial effects, cohort-specific variation in recent growth was observed (ANCOVA, different slopes, $p=0.004$ ) and, similar to instantaneous growth coefficients, recent growth was highest for mid-season cohorts (Table 2).
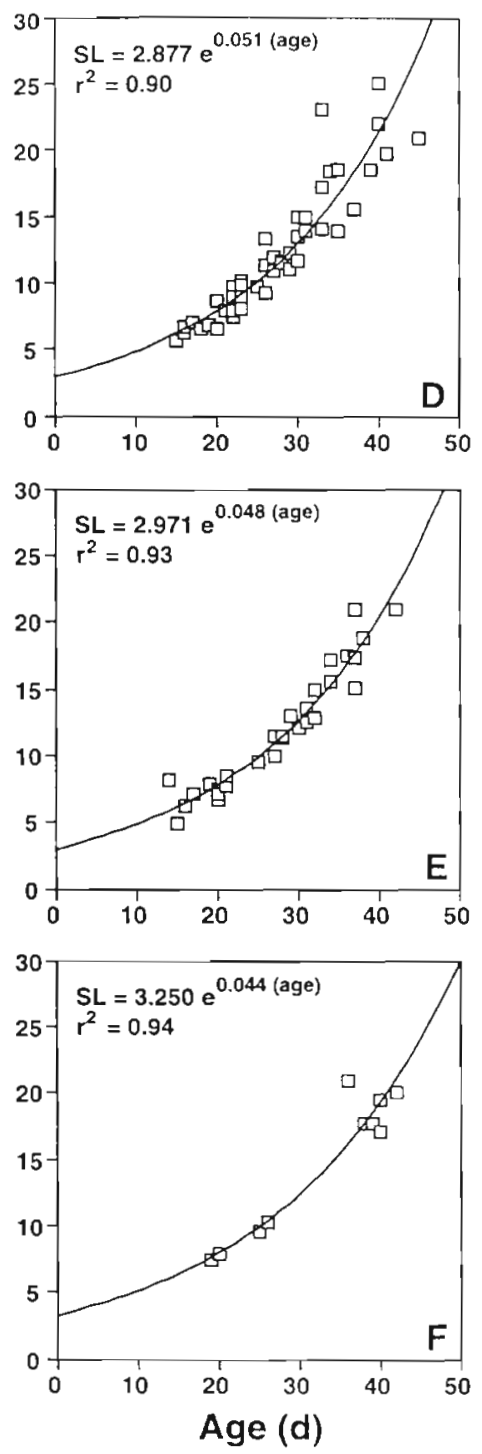

Fig. 5. Sciaenops ocellatus. Exponential relationships between age and standard length among successive red drum cohorts (A to F) from the Aransas Estuary

\section{DISCUSSION}

\section{Spatial and temporal distribution}

Our results suggest that seagrass meadows within the Aransas Estuary serve as nursery grounds for newly settled red drum and patterns of habitat utilization are seagrass-specific. Although Halodule wrightii and Thalassia testudinum meadows were both occupied, red drum densities were markedly higher in $H$. wrightii. Variability in red drum density is potentially the result of differences in the structural complexity of these habitats. Several studies have demonstrated that foraging success of predators can be reduced by 

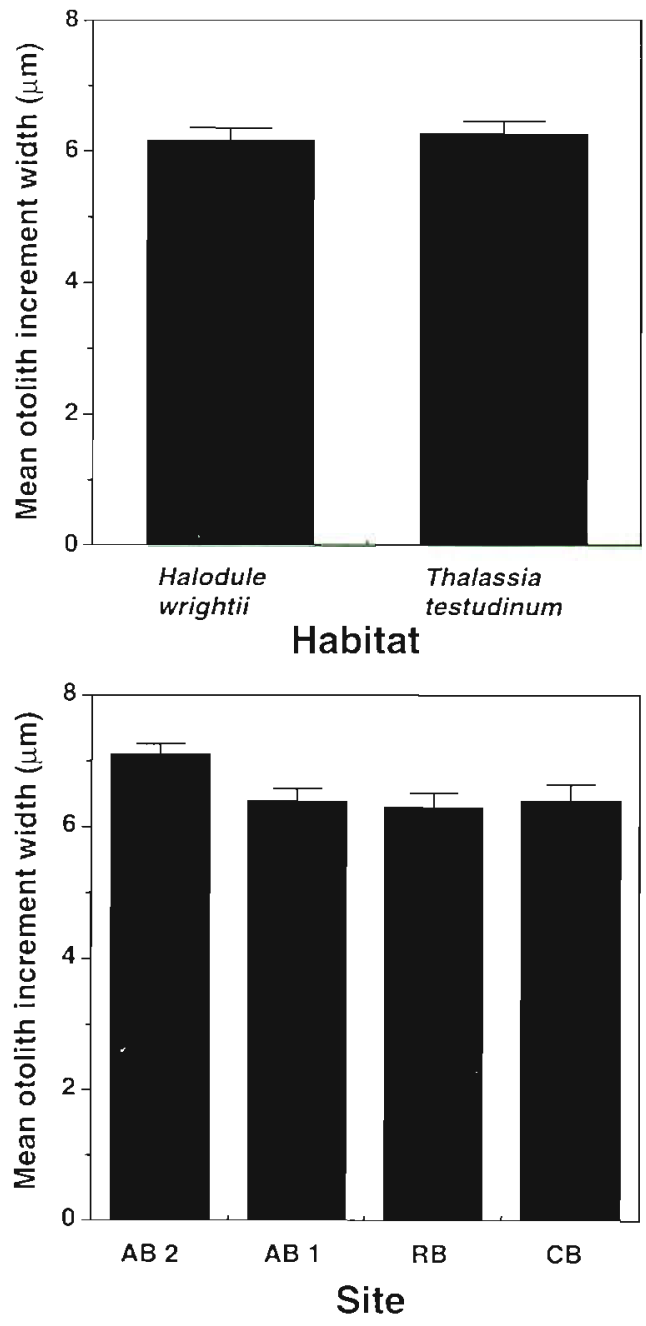

Fig. 6. Sciaenops ocellatus. Adjusted mean otolith increment widths of red drum larvae and juveniles from the Aransas Estuary by habitat (Halodule wrightil and Thalassia testudinum) and site (Aransas Bay (AB1, AB2), Redfish Bay (RB). and Corpus Christi Bay $(\mathrm{CB}) \mid$

macrophyte complexity (e.g. shoot or blade density, biomass) (Coen et al. 1981, Stoner 1982, Stoner \& Livingston 1984, Ryer 1988, Heck \& Crowder 1991). As complexity increases, the visibility of prey (encounter rate) declines and predator movement is restricted (Stoner 1980, Savino \& Stein 1989). In south Texas, shoot density of $H$. wrightii is often 8 to 10 times higher than T. testudinum (Czerny \& Dunton 1994); therefore, it is possible that red drum residing in $H$. wrightii are less vulnerable to predators.

On a larger scale, spatial patterns in larval distribution among inshore sites are commonly attributed to hydrodynamic processes (i.e. tidal currents) which have a major influence on both dispersal of larvae (i.e. larval supply) and location of initial settlement (Weinstein 1988, Jenkins et al. 1996). Tidal flows and nonlo- cal forcing mechanisms were responsible for movement of sciaenid larvae through tidal inlets and channels in North Carolina, USA (Pietrafesa \& Janowitz 1988). Similarly, tidal excursions may be vital in determining the distribution of red drum in demersal seagrass habitats in the Aransas Estuary. Offshore water entering the Aransas Estuary must first move through the Aransas Pass which divides into 3 channels (see Fig. 1). Tidal flow rates in the 3 channels leading to Aransas Bay (Lydia Ann Channel), Corpus Christi Bay (Corpus Christi Channel), and Redfish Bay (Aransas Channel) were recently measured (Ruben Solis, Texas Water Development Board, pers. comm.). Results from summer surveys in 1994 and 1995 showed that tidal flow rates in Lydia Ann Channel were 4 to 6 times greater than Aransas Channel. This is of particular interest since the density of newly settled red drum in Aransas Bay was approximately 3-fold higher than Redfish Bay, suggesting that tidal flow rate may be positively related to the larval supply. In Corpus Christi Bay, the only sampling site was relatively far removed and indirectly connected to the water conduit from the Aransas Pass. Although flow rates in the channel were relatively high, densities of newly settled red drum in this site were typically lower than other sites. Therefore, differential tidal flow rates appear to affect the supply of larvae and subsequent distribution of newly settled red drum within the Aransas Estuary; however, other contributing factors (e.g. tidal prism geometry spatial distribution of larvae in the pass, spatial variability in seagrass coverage) may strongly influence distribution patterns.

Temporal variation in the number of new settlers to estuarine nurseries is primarily the result of spawning time (hatch date), hydrodynamic processes, and differential mortality during the pre-settlement stage, which regulates larval supply. Our present knowledge regarding the temporal relationship between tidal transport and larval supply to the Aransas Estuary is limited and thus precludes interpretation. However, the use of otolith-based methods provides vital information on temporal variability in hatch-date distribution or spawning date (ca $24 \mathrm{~h}$ before hatch date). While a protracted spawning season is the common reproductive strategy of many sciaenids living in subtropical waters (e.g. Devries \& Chittenden 1982, Brown-Peterson et al. 1988, McMichael \& Peters 1989), red drum spawning is limited in duration. In this study, over $95 \%$ of all red drum collected in 1994 were from September and October spawns. Our results on spawning seasonality are consistent with findings reported in the north-central Gulf of Mexico (Comyns et al. 1991) and in Florida, USA (Peters \& McMichael 1987). The hatch-date distribution also indicated that spawning intensity was relatively continuous through- 
out the primary spawning period (September-October). In support of this finding, recent examination of daily red drum egg production from the Aransas Pass tidal inlet indicated that spawning activity occurred daily from late August to late October in 1994 (S. A. Holt unpubl. data). This study and the previous studies discussed above described the spawning seasonality of red drum based on either the timing of egg production or hatch-date distributions from otoliths. Since hydrodynamic events may strongly influence the delivery of eggs and larvae to the various collection sites, it is possible that certain spawns never enter the estuary and thus evidence of this nature may be inherently biased.

\section{Variation in growth rate and the recent $5 \mathrm{~d}$ growth index}

All cohorts of newly settled red drum grew rapidly in 1994 ( 0.5 to $0.8 \mathrm{~mm} \mathrm{~d}^{-1}$ ) and growth was highest for the most abundant cohorts, suggesting that there are no negative effects of density on growth. Growth rates were similar to estimates reported by Peters \& McMichael (1987) for red drum in Tampa Bay, Florida. The size-at-age equation estimated that the mean length of 20 and $40 \mathrm{~d}$ individuals from Tampa Bay was 9.0 and $20.5 \mathrm{~mm}$ SL, respectively. Similarly, the mean lengths of 20 and $40 \mathrm{~d}$ individuals from the Aransas Estuary (based on all cohorts pooled) were 7.7 and $20.2 \mathrm{~mm} \mathrm{SL}$, respectively. Surface water temperature ranges in Tampa Bay $\left(18\right.$ to $\left.30^{\circ} \mathrm{C}\right)$ and the Aransas Estuary $\left(20\right.$ to $29^{\circ} \mathrm{C}$ ) were relatively similar, permitting such comparisons.

Temperature is a major determinant of growth variation in laboratory-reared red drum (Holt et al. 1981, Lee et al. 1984). Similarly, our recent growth index for newly settled red drum from the Aransas Estuary confirmed the influence of temperature on growth. By comparing recent growth rates to temperature (mean of $5 \mathrm{~d}$ prior to capture) on individual sampling trips, we determined that growth was positively associated with temperature. Mean temperature ranged from 21.0 to $27.5^{\circ} \mathrm{C}$ which resulted in a $13 \%$ difference in the recent growth index $\left(2 \%\right.$ per ${ }^{\circ} \mathrm{C}$ increase). This difference in recent growth (i.e. otolith growth) among temperatures may not directly correspond to somatic growth since a lagged response of otolith growth to fish growth may be present (Neilson \& Geen 1984). In contrast to the recent growth index, no relationship between long-term growth rates of successive cohorts and temperatures could be shown for red drum in the Aransas Estuary. By averaging temperatures over the first $20 \mathrm{~d}$ since post-hatch, we determined that mean temperature experienced by successive cohorts declined continually from the first $(A)$ to the last $(F)$ cohort. However, instantaneous growth coefficients were highest for cohorts $\mathrm{C}$ and $\mathrm{D}$. Therefore, temporal variation in other growth-regulating factors (e.g. prey availability) may be responsible for differences in growth among cohorts.

Growth variation and survival of marine fish larvae are often associated with prey abundance (Lasker 1975, Houde \& Schekter 1981). Houde (1978) demonstrated that growth and survival of 3 species of marine fish larvae were positively associated with zooplankton density. Similarly, growth variation in laboratoryreared red drum has been regulated by zooplankton density (G. Joan Holt pers. comm.). The effect of prey density on recent growth rates of wild red drum could not be evaluated directly in this study since no estimates of prey availability were made. Since spatial and temporal variability in prey density (i.e. meiofauna) are common in estuarine habitats off south Texas (Montagna \& Kalke 1992), it is possible that changes in prey availability during the 1994 settlement period resulted in growth variation among cohorts. The inclusion of such information in future studies should enhance the predictive power of recent growth models and assist in the explanation of differential growth rates.

\section{Relationship between habitat selection and growth}

Rapid growth leads to increased size and a shorter stage duration which results in lower predator-mediated mortality rates (Bailey \& Houde 1989). As a result, we generally expect individuals to reside in nursery habitats where their growth potential is maximized. However, in order for individuals to maximize survival they must effectively manage the tradeoff between being the predator or the prey. Sogard (1992) reported that winter flounder [Pleuronectes (= Pseudopleuronectes) americanus] densities matched growth patterns. However, she also observed that highest natural densities of the naked goby Gobiosoma bosc were present in the poorest habitats for growth. When fish densities do not match growth patterns it is assumed that compromises or tradeoffs are occurring.

It is selectively advantageous for individuals to reside in habitats that maximize the ratio of growth to mortality $(G: Z)$ (Werner \& Gilliam 1984). In this study, we observed that growth rates were fairly uniform between habitats. Recent studies on the biochemical condition (Rooker et al. 1997) and feeding ecology (Soto 1997) of newly settled red drum from the Aransas Estuary reported similar results. Biochemical condition (correlated with nutritional state and growth) (Rooker \& Holt 1996) and foraging efficiency (gut fullness) of red drum were relatively uniform between Halodule wrightii and Thalassia testudinum. Since growth rates 
(G) were similar between habitats, we would expect newly settled red drum to select habitats where mortality rates $(Z)$ are lowest or rather habitats that minimize predator efficiency. As discussed earlier, habitats with greater complexity (e.g. H. wrightil) potentially confer added protection from predators. Therefore, it is reasonable to postulate that habitat selection patterns observed in the Aransas Estuary in 1994 were the result of anti-predator behaviors rather than spatial variability in growth and foraging conditions.

Acknowledgements. We thank Kathy Binney, Patti Pickering, Cameron Pratt, and Andy Soto for providing assistance in the laboratory and field. Joan Holt, Chris Onuf, Kirsten Poling, and 3 anonymous reviewers provided constructive criticism and helpful suggestions. This work was supported by grants from the Texas Higher Education Coordinating Board Advanced Research Program (Grant No. 003658-392), Texas A\&M Sea Grant Program (Grant No. NBR:RIF65), Sid W Richardson Foundation, and fellowships to J.R.R. (E. J. Lund, Julian C. Barton). This is contribution no. 1012 of The University of Texas at Austin, Marine Science Institute

\section{LITERATURE CITED}

Bailey KM, Houde ED (1989) Predation on egg and larvae of marine fishes and the recruitment problem. Adv Mar Biol 25:1-83

Brothers EB (1981) What can otolith microstructure tell us about daily and subdaily events in the early life history of fish? Rapp PV Réun Cons Int Explor Mer 178:393-394

Brown AL, Bailey KM (1992) Otolith analysis of juvenile walleye pollock Theragra chalcogramma from the western Gulf of Alaska. Mar Biol 112:23-30

Brown-Peterson N, Thomas P, Arnold CR (1988) Reproductive biology of the spotted seatrout, Cynoscion nebulosus, in south Texas. Fish Bull US 86:373-388

Campana SE, Neilson JD (1985) Microstructure of fish otoliths. Can J Fish Aquat Sci 42:1014-1032

Coen LD, Heck KL Jr, Abele LG (1981) Experiments on competition and predation among shrimps of seagrass meadows. Ecology 62:1484-1493

Comyns BH, Lyczkowski-Shultz J, Nieland DL, Wilson CA (1991) Reproduction of red drum, Sciaenops ocellatus, in the northcentral Gulf of Mexico: seasonality and spawner biomass. NOAA Tech Rep NMFS 95:17-26

Comyns BH, Lyczkowski-Shultz J, Rakocinski CF, Steen JR Jr (1989) Age and growth of red drum larvae in the northcentral Gulf of Mexico. Trans Am Fish Soc 118.159-167

Czerny AB, Dunton KH (1994) The effects of in situ light reduction on the growth of two subtropical seagrasses, Thalassia testudinum and Halodule wrightii. Estuaries 18: $418-427$

Devries DA, Chittenden ME Jr (1982) Spawning, age determination, longevity, and mortality of the silver seatrout, Cynoscion nothus, in the Gulf of Mexico. Fish Bull US 80: $487-500$

Fuiman LA (1989) Vulnerability of Atlantic herring larvae to predation by yearling herring. Mar Ecol Prog Ser 51. 291-299

Fuiman LA (1994) The interplay of ontogeny and scaling in the interactions of fish larvae and their predators. J Fish Biol 45:55-79

Fuiman LA, Magurran AE (1994) Development of predator defences in fishes. Rev Fish Biol Fish 4:145-183

Gamble JC, Hay SJ (1989) Predation by the scyphomedusan Aurelia aurita on hernng larvae in large enclosures: effects of predator size and prey starvation. Rapp PV Réun Cons Int Explor Mer 191:366-375

Geffen AJ (1982) Otolith ring deposition in relation to growth rate in herring (Clupea harengus) and turbot (Scophthalmus maximus\} larvae. Mar Biol 71:317-326

Heck KL Jr, Crowder LV (1991) Habitat structure and predator-prey interactions in vegetated aquatic systems. In: Bell SS, McCoy ED, Mushinsky HR (eds) Habitat complexity: the physical arrangement of objects in space. Chapman and Hall, New York, p 281-289

Holt GJ (1993) Feeding larval red drum on microparticulate diets in a closed recirculating water system. J World Aquacult Soc 24:225-230

Holt GJ, Godbout R, Arnold CR (1981) Effects of temperature and salinity on egg hatching and larval survival of red drum, Sciaenops ocellata. Fish Bull US 79:569-573

Holt SA, Kitting CL, Arnold CA (1983) Distribution of young red drums among different sea-grass meadows. Trans Am Fish Soc 112:267-271

Houde ED (1978) Critical food concentrations for larvae of three species of subtropical marine fishes. Bull Mar Sci 28: $395-411$

Houde ED (1987) Fish early life dynamics and recruitment variability. Am Fish Soc Symp 2:17-29

Houde ED, Schekter JD (1981) Growth rates, rations and cohort consumption of marine fish larvae in relation to prey concentration. Rapp PV Réun Cons Int Explor Mer 178:441-453

Hovencamp F, Witte JIJ (1991) Growth, otolith growth and RNA:DNA ratios of larval plaice Pleuronectes platessa in the North Sea 1987-1989. Mar Ecol Prog Ser 70;105-116

Jenkins GP, Wheatley MJ, Poore AGB (1996) Spatial variation in recruitment, growth, and feeding of postsettlement King George whiting, Sillaginodes punctata, associated with seagrass beds of Port Phillip Bay, Australia. Can J Fish Aquat Sci 53:350-359

Jones $C$ (1986) Determining the age of larval fish with the otolith increment technique. Fish Bull US 84:91-103

Lasker R (1975) Field criteria for survival of anchovy larvae: the relation between inshore chlorophyll maximum layers and successful first feeding. Fish Bull US 73:453-462

Lee WY, Holt GJ, Arnold CR (1984) Growth of red drum larvae in the laboratory. Trans Am Fish Soc 113:243-246

Leggett WC, Deblois E (1994) Recruitment in marine fishes: is it regulated by starvation and predation in the egg and larval stages? Neth J Sea Res 32:119-134

McMichael RH Jr, Peters KM (1989) Early life history of spotted seatrout, Cynoscion nebulosus (Pisces: Sciaenidae), in Tampa Bay, Florida. Estuaries 12:98-110

Miller TJ, Crowder LB, Rice JA, Marschall EA (1988) Larval size and recruitment in fishes: toward a conceptual framework. Can J Fish Aquat Sci 45:1657-1670

Moksness E, Rukan K, Ystanes L, Folkvord A, Johannessen A (1994) Comparison of somatic and otolith growth in North Sea herring (Clupea harengus L.) larvae: evaluation of growth dynamics in mesocosms. In: Secor D, Dean J, Campana $S$ (eds) Recent developments in fish otolith research. University of South Carolina Press, Columbia, p 119-134

Montagna PA, Kalke RD (1992) The effect of freshwater inflow on meiofaunal and macrofaunal populations in the Guadalupe and Nueces Estuaries, Texas. Estuaries 15: $307-326$

Neilson JD, Geen GH (1984) Effects of feeding regimes and diel temperature cycles on otolith increment formation in 
juvenile chinook salmon Oncorhynchus tshawytscha. Fish Bull US 83:91-101

NOAA (1991) Our living oceans. First annual report on the status of U.S. living marine resources. NOAA Tech Memo NMFS-F/SPO-1

Pannella G (1971) Fish otoliths: daily growth layers and periodical patterns. Science 173:1124-1127

Peters KM, McMichael RH Jr (1987) Early life history of the red drum Sciaenops ocellatus (Pisces: Sciaenidae) in Tampa Bay, Florida. Estuaries 10:92-107

Pietrafesa LJ, Janowitz GS (1988) Physical oceanographic processes affecting larval transport around and through North Carolina inlets. Am Fish Soc Symp 3:34-50

Post JR, Evans DO (1989) Experimental evidence of sizedependent predation mortality in juvenile yellow perch. Can J Zool 67:521-523

Radtke RL (1989) Larval fish age, growth, and body shrinkage: information available from otoliths. Can J Fish Aquat Sci 46:1884-1894

Rooker JR (1997) Condition, growth and mortality of newly settled red drum (Sclaenops ocellatus) in subtropical seagrass meadows. PhD dissertation, The University of Texas at Austin

Rooker JR, Holt GJ (1996) Application of RNA:DNA ratios to evaluate the condition and growth of larval and early juvenile red drum (Sciaenops ocellatus). Mar. Freshwater Res 47:283-290

Rooker JR, Holt GJ, Holt SA (1997) Condition of larval and juvenile red drum (Sciaenops ocellatus) from estuarine nursery habitats. Mar Biol 127:387-394

Ryer CH (1988) Pipefish foraging: effects of fish size, prey size and altered habitat complexity. Mar Ecol Prog Ser 48 : $37-45$

Savino JF, Steln RA (1989) Behavioral interactions between fish predators and their prey: effects of plant density. Anim Behav 37:311-321

Secor DH. Houde ED (1995) Temperature effects on the timing of striped bass egg production, larval viability, and recruitment potential in the Patuxent River (Chesapeake Bay). Estuaries 18:527-544

Sinclair M (1988) Marine populations. Washington Sea Grant Program, Seattle

Sogard SM (1991) Interpretation of otolith microstructure in juvenile winter flounder (Pseudopleuronectes americanus): ontogenetic development, daily increment validation, and somatic growth relationships. Can J Fish Aquat Sci $48: 1862-1871$

Editorial responsibility: Kenneth Heck, Jr (Contributing Editor), Dauphin Island, Alabama, USA
Sogard SM (1992) Variability in growth rates of juvenile fishes in different estuarine habitats. Mar Ecol Prog Ser 85: $35-53$

Sogard SM, Able KW (1992) Growth variation of newly settled winter flounder (Pseudopleuronectes americanus) in New Jersey estuaries as determined by otolith microstructure. Neth J Sea Res 29:163-172

Sokal RR, Rohlf FJ (1981) Biometry, 2nd edn. WH Freeman, San Francisco

Soto MA (1997) Food habits and resource partitioning of larval and juvenile red drum (Sciaenops ocellatus) and Atlantic croaker (Micropogonias undulatus). MSc thesis, Texas A\&M University-Kingsville, Kingsville

Stoner AW (1980) The role of seagrass biomass in the organization of benthic macrofaunal assemblages. Bull Mar Sci $30.537-551$

Stoner AW (1982) The influence of benthic macrophytes on the foraging behavior of pinfish, Lagodon rhomboides (Linnaeus). J Exp Mar Biol Ecol 58:271-284

Stoner AW, Livingston RJ (1984) Ontogenetic patterns in diet and feeding morphology in sympatric sparid fishes from seagrass meadows. Copeia 1984:174-187

Suthers IM, Frank KT, Campana SE (1989) Spatial comparison of recent growth in postlarval Atlantic cod (Gadus morhua) off southwestern Nova Scotia: inferior growth in a presumed nursery area. Can $J$ Fish Aquat Sci 46: $113-124$

Swingle WE (1990) Status of the commercial and recreational fishery. In: Chamberlain GW, Miget RJ, Haby MG (eds) Red drum aquaculture. TAMU-SG-90-603. Texas A\&M Sea Grant Program, College Station, p 22-24

Volk EC, Wissmar RC, Simenstad CA, Eggers SM (1984) Relationship between otolith microstructure and the growth rate of juvenile chum salmon (Oncorhynchus keta) under different prey ratios. Can J Fish Aquat Sci 41:126-133

Webb PW, Corolla RT (1981) Burst swimming performance of northern anchovy, Engraulis mordax, larvae. Fish Bull US $79: 143-150$

Weinstein $M$ (1988) Larval fish and shellfish transport through inlets. Am Fish Soc Symp 3

Werner EE, Gilliam JF (1984) The ontogenetic niche and species interactions in size-structured populations. Annu Rev Ecol Syst 15:393-425

Wilson KH, Larkin PA (1982) Relationship between thickness of daily growth increments in sagittae and change in body weight of sockeye salmon (Oncorhynchus nerka) fry. Can J Fish Aquat Sci 39:1335-1339

Submitted: December 16, 1996; Accepted: September 4, 1997 Proofs recelved from author(s): October 23, 1997 